\title{
Proposed Integrated Performance Management System for Ministry of Research, Technology, and Higher Education in Indonesia
}

\author{
Emilia Stella \\ Magister of Business Administration Program, School of \\ Business and Management, Bandung Institute of \\ Technology \\ Bandung, West Java, Indonesia \\ emilia.stella@sbm-itb.ac.id
}

\author{
Dermawan Wibisono \\ Magister of Business Administration Program, School of \\ Business and Management, Bandung Institute of \\ Technology \\ Bandung, West Java, Indonesia \\ dwibisono@sbm-itb.ac.id
}

\begin{abstract}
As a developing country, Indonesia still concentrates on better and sustainable quality of life. With that condition, Indonesia has to implement knowledge transfer. The model has shown the importance of knowledge transfer produced from education system, especially from higher education which produces people who are ready to contribute economically and socially to the country. Therefore, higher education as the part of the Ministry of Research, Technology and Higher Education is important to be assessed, especially regarding its performance.

Each ministry has Accountability and Government Instance Performance Report or LAKIP which reports the ministries' performance each year. Unfortunately, the ministries' performance framework formulation is done only based on the objectives, not based on the vision and mission, which causes performance management system or PMS not to be comprehensively formulated and implemented. Moreover, not all Key Performance Indicators or KPIs used show the improved, declining, or actual performance. In addition, the PMS is formulated internally in each ministries, therefore the performance management system does not have wider suggestion and comparison for the best practice for developed .

This research objective is to create a proposed performance management system (PMS) which is suitable to the ministry for further evaluation, diagnosis, and follow up in order to create a continuous improvement and sustainable development of Indonesia.

Using the Integrated Performance Management System or IPMS from Wibisono, 2012, a simple understandable framework can be proposed which can show the comprehensive performance for non-profit organization. Additionally, it may do bench-marking externally to developed countries, so that the performance management system produced can be assessed properly. In this topic, the performance formulation is done in the corporate level, therefore the implementation needs further formulation for each level in the ministry level.
\end{abstract}

Keywords - performance management system; integrated performance management system; non-profit organization; Indonesia's ministries

\section{INTRODUCTION}

Indonesia's ministries are Indonesia's agency which takes responsibilities of certain matters in the government. The formation of ministries is based on Chapter V Article 17 Undang-Undang Dasar (UUD) 1945 which states that President is assisted by state ministers, ministers are appointed and dismissed by President, each minister is in charge of specific affairs in the government, and the formation, alteration and dissolution of the state ministries are regulated by law.

The existing ministry after the seventh president of Indonesia Ir. Joko Widodo took the oath as president can be divided into four categories. The first category is the coordinating ministries, which are appointed by the president to be the head of the functional ministries (ministries for the certain scope which place in the third and fourth categories). The second category is the ministries that are mentioned in the UUD 1945 and are responsible for the government affairs. The third category is the ministries for certain scope function. Last but not least, the fourth category is the ministries that are appointed for sharpening, coordinating, and synchronizing the government program.

Ministry of Research, Technology, and Higher Education is in the category of ministries for certain scope function. This ministry is in the part of Ministry of Research, Technology and Higher Education. The ministry is chosen because it is the key to produce people who are ready to contribute to the society, as the agent of knowledge transfer, and also as the agent of economic development for the country.

Because of the important responsibilities and function of ministries, the effectiveness of each ministry performance report is essential. The existing performance report for each ministry is Laporan Akuntabilitas dan Instansi Pemerintah (LAKIP), as a fulfillment to Instruksi Presiden Nomor 7 Tahun 1999. LAKIP is a form of ministry's accountability and transparency in actuating its tasks and obligations according 
to plan and target in the beginning of year. In addition, LAKIP is formed to show its responsibility in achieving organization vision and mission through objectives which have been assigned. This responsibility also relates to the government budget, regarding of how they use the budget in government activities.

Ministry's performance is measured in LAKIP through Key Performance Indicators (KPI). On May 31, 2007 the Ministry of Administrative Reform and Bureaucratic Reform issued a Ministerial Regulation no PER/9/M.PAN/5/2007 General Guidelines Determination of Key Performance in the Government Environment, which became the guidelines for each ministry to determine the KPI. However, this KPI formulation is performed internally, which makes it impossible to have wider suggestion. Moreover, this guideline guarantee is still questionable and has to be analyzed further in order to achieve effectiveness of performance management system.

The important role of higher education performance is also shown in below statement according to Reference [1], "... nation-states that concentrate on the progress of society, higher competitiveness of their economies, or better and sustainable quality of life have to apply the resource of knowledge". Knowledge is created through a series of creative processes, combinations and productions, so-called 'Knowledge models', 'Innovation models', or 'Knowledge creation'. As developing country, Indonesia still concentrates on better and sustainable quality of life, so this knowledge model is appropriate.

The famous model of knowledge creation and innovation creativity is Triple Helix which emphasizes the trilateral networks and hybrid organizations of university-industrygovernment relations. The development of this model comes to Quadruple Helix which adds public (defined as the 'mediabased and culture-based public' and civil society), as the fourth helix and is further developed to Quintuple Helix which adds natural environment as fifth helix [1].This five helix will work by the flow of knowledge to be transferred, in order to produce innovation in each sub-chapters, and will achieve sustainable development. The figure of Quintuple Helix model can be seen in Figure 1.

Fig 1. Quintuple Helix model [1]

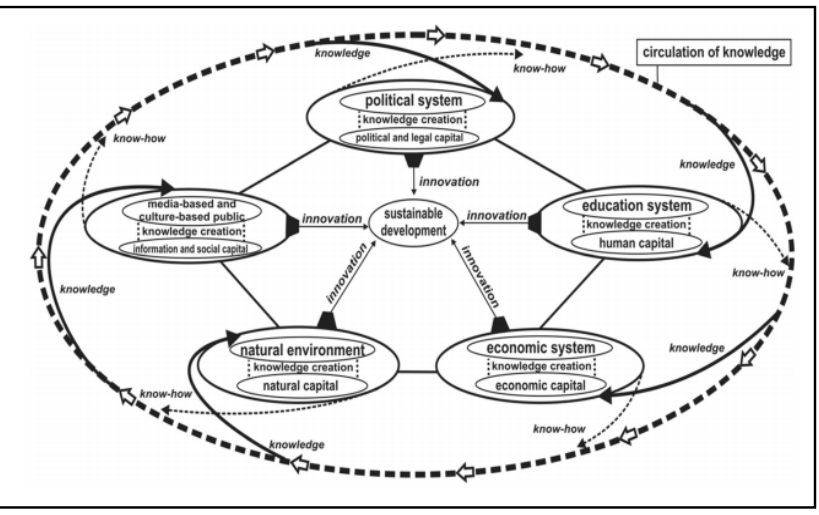

\section{BUSINESS ISSUE EXPLORATION}

\section{A. Conceptual Framework}

Performance management can be defined as systematic process which ensures that organizations can consistently meet their goals in an effective and efficient manner through organizing their resources and process to certain strategic objectives. Due to the business environment changes, which cause the business strategy changes, the need of complement performance management system beside the accounting reports are essential.

The weaknesses of accounting reporting have been defined by Kaplan (1983) and Cooper and friends (1992) as lack of relevance, lagging metrics, short-termed, inflexible, and do not foster improvement and cost distortion. Some of the existing frameworks like Balanced Scorecard (BSC), Malcolm Baldrige Quality Award (MBNQA), and International Standard Organization (ISO); have had their own criticism. For instance, ISO has been criticized to be implemented by most of companies for just obtaining certification, not updating its consistency and commitment. It therefore results in not improving their performance. Malcolm Baldrige also criticizes for answering the leading questions to obtain high scores. BSC also gets critics for its final focus on financial performance, not-statistical support for variable, linkage, and no room for bench-marking [2].

According to Reference [2], even there is a lot of criticism on the existing framework, the exact and agreed performance measurement method to replace the conventional organization performance reporting system has not been discovered until now. . However, the experts have agreed of criteria which have to be fulfilled for effective Performance Management System (PMS). There are two suggestions from Maskell (1981) and Globerson (Stoop, 1996) in early 1990. Maskell (1981) suggests seven criteria that should be fulfilled. The seven criteria are :

- performance management system designed should have direct linkage with organization strategy

- the measured variable should use non-financial measurement

- the designed PMS should be flexible and varied.

- the designed PMS has to be dynamic, always be updated every time

- the designed PMS has to be simple and easy to be operated

- the designed PMS has to be probable for fast feedback for every level of managerial

- the designed PMS has to be purposed for implementation process, not only monitoring process.

Globerson (1996) also loads some complements for other criteria of PMS design:

- the designed PMS has to be used for bench-marking

- the purpose of PMS design should be clearly defined

- in determining the amount of variable, ratio variable usage is preferable compared to absolute number

- quantitative performance criteria is preferable than qualitative 
With those criteria, it is expected that performance management can lead to improvement performance, for all organization, including government. Based on Redburn et.al in the book Performance Management and Budgeting : How Government Can Learn From Experience, "government can improve their performance over time not by simple trial and error, but by systematically analyzing what works and what doesn't and translating the information into decision about where to put their resources, how to manage, and how to improve program design" [3].

The relationship between sustainable development and performance management has been proved in China. Even initially, there was a heavy emphasis on the economic focus result, but performance management helps to improve the social and public service functions and sustainable development[4]. Moreover, the role of performance management is crucial due to some declining fund sources issues, while the demand for the result is increasing [5]. These statements have emphasized that PMS has critical role in improving government performance.

\section{B. Performance Management System (PMS) Design}

Until now, there is still no guidance for the required framework for PMS. In this project, the methodology is created by Dermawan Wibisono for his experience in designing PMS and it implements several frameworks which have been known internationally. The methodology for PMS design can be defined in Figure 2.

Fig 2. Integrated Performance Management System Methodology [2]

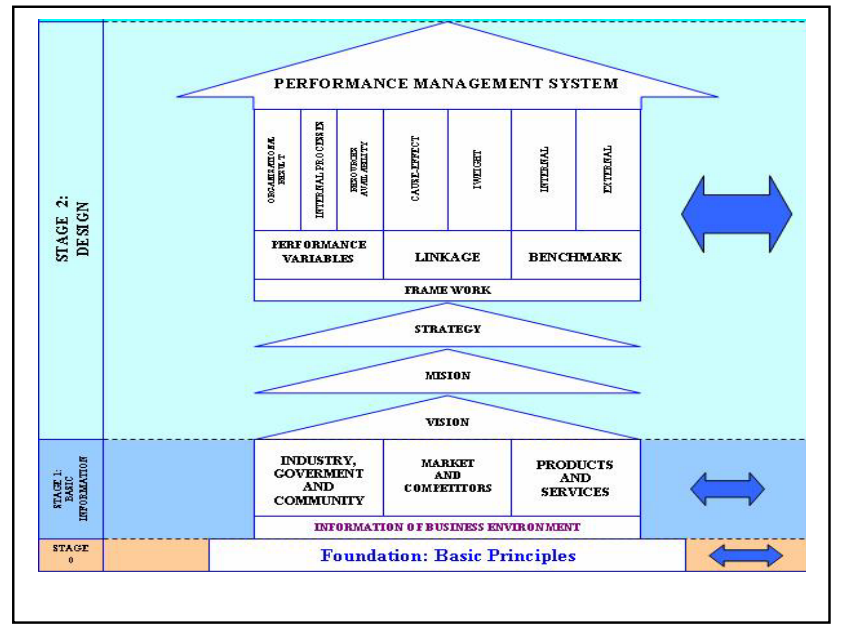

From the four step for designing PMS, the central role for PMS design is in stage 1 and 2. Therefore, this final project is focused in designing PMS for Ministry of Research, Technology and Higher Education, which is in the stage 1 and stage 2. The integration for this topic is the fourth perspective (financial support perspective) as the movement from financial component in business result, and becomes the base for the three perspectives. This movement is done because ministry as non-profit organization does not aim the financial perspective.
Since the data source for this project is limited on accountability and performance government report (LAKIP), the factors that need to be evaluated comprise:

- Vision and mission analysis

- existing performance variables and indicators

- performance indicators suggestion by doing benchmarking with developed countries

For the needed evaluation above, there are some conceptual frameworks which can be used from Wibisono, 2012 .

\section{1) Vision and Mission Analysis}

Vision is a statement of goal or dream which a company or organization wants to achieve in the future (want to be statement). Vision implies the organization future in 3 up to 10 years ahead, which is very important to generate for some motives:

- unification of company's purposes, directions and target

- basic utilization and allocation of resources as well as its control

- to establish and build corporate cultures

Based on "How to Create A World Class Company" book [2], good vision has the following criteria:

- stated company's goals or dreams in the future

- brief, clear, focus and standard of excellence

- realistic sets and is in accordance with company's competence

- attractive goals and the ability to inspire commitment and enthusiasm

- is easy to remember and understood by all of the staffs, and impresses the stakeholders

- level of achievement that can be traced.

For mission analysis, based on chapter 3 of How to Create a World Class Company, it is stated that mission is series of sentences stating the goals or reason of organization existence and hold things about what the company provides to the society, either in the form of products or services[6]. Mission helps to show the uniqueness of the companies and at the same time, is very important to lead the company to the right direction.

Essentially, there are five important elements which have to be included in mission statement. The five elements are:

- nature of business consideration from the company

- considering responses from customer perspectives, not only from the company itself

- reflecting the organizations' basic value and confidence

- reflecting the continuous competitive advantage element

- embracing the main reason from the approaches which the company has chosen

\section{2) Performance Variable Selection}

There are two performance variable types, quantitative and qualitative variable. However, quantitative variable is 
preferable because it is more objective and does not create undesired interpretation.

The variable selection should be done because some of variable are meaningless for only showing fact but not showing the performance. Some variable examples that should be avoided are number of employees attending the training, number of researchers' publication, number of employee recommendation, and number of repaired processes. Some typical mistakes from performance variable selection should be avoided:

- critical variables that have not been listed

- too many variable managed

- lack of meaning variable

- wrong emphasize on variable

- difficult to be translated and implemented

- bias between the focus for improvement and control

3) Bench-marking

Bench-marking can be defined as the process to compare the process or result of internal organization to other organizations in order to improve the company performance. These activities can generate revolution from new point of view and new ideas. Some of reasons for bench-marking:

- to create fast performance improvement,

- to shorten required time to do changes,

- to help achieve goals and effective calculation,

- to give new spirit in achieving success, new ideas and innovation

- to ensure the best practice has been used in the work process

The summary of conceptual framework and the proposed PMS design from the above explanation can be seen in Figure 3.

Fig 3. Conceptual framework and Proposed PMS

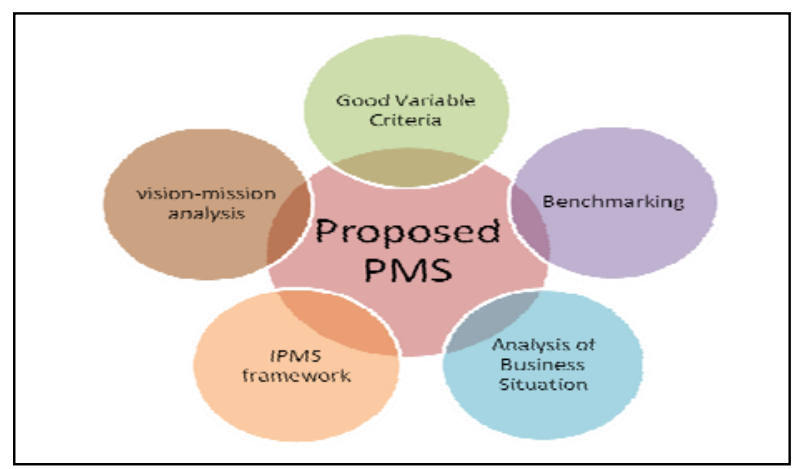

The proposed PMS design is the combination of vision analysis and formulation, mission analysis and formulation, strategy formulation, four PMS perspectives, is added with short/medium /long-term objectives through bench-marking to the existing objectives, is added KPIs by doing benchmarking through existing KPIs analysis through good criteria analysis, and is concluded the performance measurement result for each country from trusted sources.

\section{ANALysis Of Business SituAtion}

Indonesia is a developing country which still struggles with some major issues in uneven development and life opportunities. This section will define issues in the ministry which represent the condition.

According to 2015-2019 Strategic Plan of Ministry of Research, Technology and Higher Education [7], the performance of high education in 2010 to 2014 has improved the access of education, but still lack of improvement in the quality and competitiveness of higher education. In addition, there are improvements in producing qualified human resources to fulfill society needs to become problem solver and to participate in building a sustainable development of society.

Higher education has a critical role in utilizing Indonesian rich potential on natural resources which can be converted to food materials, energy, and health drugs. It may also generate industrial competitiveness on business and technology. According to Global Competitiveness Report (GCR), Indonesia is ranked on 34 in 2014-2015, but still left behind, compared to Singapore (2nd), Malaysia (20th), and Thailand (31st).

This fact shows that Indonesia higher education still cannot compete with other countries, even with ASEAN countries. Moreover, the top universities in Indonesia are still in the low rank in international universities survey. The competitiveness of Indonesia graduates also relates to the certification and profession education which is still very limited. To anticipate Economic ASEAN Community, certification for professional needs to be enhanced in orders to compete domestically and internationally.

The relevance of graduates and employer demands on graduates and the curriculum designed in higher education and professional skills has to be further comprehended. These two relevance are important to be examined because there is still unemployed educated people and educated people who work as blue-collar jobs, instead of white-collar jobs.

Moreover, Indonesia still fights to increase the access to education due to the lack of education facilities and lack of financial ability to reach education access. Therefore, there is still a lot of improvement in Ministry of Research, Technology and Higher Education.

This improvement will not be followed-up until the performance measurement is effective enough to encourage true evaluation and diagnosis. Therefore, the existing PMS of the ministry will be proposed to be changed according to the conceptual framework in the previous section. The existing Performance Measurement of Ministry of Research, Technology and Higher Education can be seen in Table 1. 
TABle I. Existing Performance Measurement of Ministry of Research, Technology and HighER EducAtion

\begin{tabular}{|c|c|}
\hline Objective & KPI (Key Performance Indicators) \\
\hline \multirow{9}{*}{$\begin{array}{l}\text { Increasing the quality of learning } \\
\text { and higher education student }\end{array}$} & Gross Enrollment Ratio (GER) Universities \\
\hline & Number of students in entrepreneurship \\
\hline & Percentage of competence certified graduates \\
\hline & Number of superior accredited study program \\
\hline & Number of students who achieve gold medal in national level \\
\hline & Number of students who achieve gold medal in international level \\
\hline & Percentage of graduates who directly work \\
\hline & Number of LPTKs which increase the quality of organizing academic education \\
\hline & The number of prospective educators to follow the Professional Teacher Education \\
\hline \multirow{5}{*}{$\begin{array}{l}\text { Increasing the quality of Science and } \\
\text { Higher Education } \\
\text { institutions }\end{array}$} & Number of higher educations that achieve top 500 universities in the world \\
\hline & Number of "A" accredited higher education \\
\hline & Number of Science and Technology Parks built \\
\hline & Number of Park and Technology Mature \\
\hline & Number of Iptek Superior Center \\
\hline \multirow{4}{*}{$\begin{array}{l}\text { Increasing the R\&D relevance and } \\
\text { productivity }\end{array}$} & Number of international publication \\
\hline & Number of registered intellectual property rights (HKI) \\
\hline & Number of R\&D prototype \\
\hline & Number of industry prototype \\
\hline \multirow[t]{2}{*}{ strengthening the capacity of innovation } & Number of innovation products which become products and give advantages to users \\
\hline & Number of organization unit whose accountability score is B (good) \\
\hline \multirow{4}{*}{$\begin{array}{l}\text { The realization of good governance and } \\
\text { the high quality of services and support in } \\
\text { every echelon in Kemenristekdikti }\end{array}$} & Percentage of budget planning efficiency \\
\hline & Service satisfaction index \\
\hline & $\begin{array}{l}\text { Assessment quality of the Ministry of PAN-RB on the implementation of the Kemenristekdikti } \\
\text { Reforms }\end{array}$ \\
\hline & Percentage of law case solved \\
\hline \multirow{6}{*}{$\begin{array}{l}\text { Increasing the relevance, quality, and } \\
\text { quantity of resources }\end{array}$} & Number of minimum S2 qualified graduates lecturer \\
\hline & Number of minimum S3 qualified graduates lecturer \\
\hline & Number of educators who held lecture certification \\
\hline & Number of research and development (R\&D)in human resource with Master and Doctor qualification \\
\hline & Number of R\&D human resource whose competencies increasing \\
\hline & Number of facilities revitalization in R\&D institution and public universities \\
\hline
\end{tabular}

\section{BUSINESS SOLUTION}

Using [2] regarding good vision criteria, it can be concluded that the vision of the ministry selected is lack of giving inspiration to employees to work comfortably. Therefore, it is generated the suggested vision. "Become Ministry of Research, Technology and Higher Education that realizes the high-quality education and increases the knowledge, technology, and innovation to support competitiveness and nation's welfare" is suggested instead of the original vision "Realizing high quality higher education and knowledge, technology, innovation and capability to support Indonesia's competitiveness".
For the mission analysis, all the ministries' missions already fulfill the good criteria of [2] on good mission. Therefore, the suggested mission is not required.

The proposed PMS designed for Ministry of Research, Technology and Higher Education will be shown in T, and the existing of the PMS design will be shown in Table 2, 3 and 4. The analysis on the existing and proposed PMS designed using the available data will be defined here. 


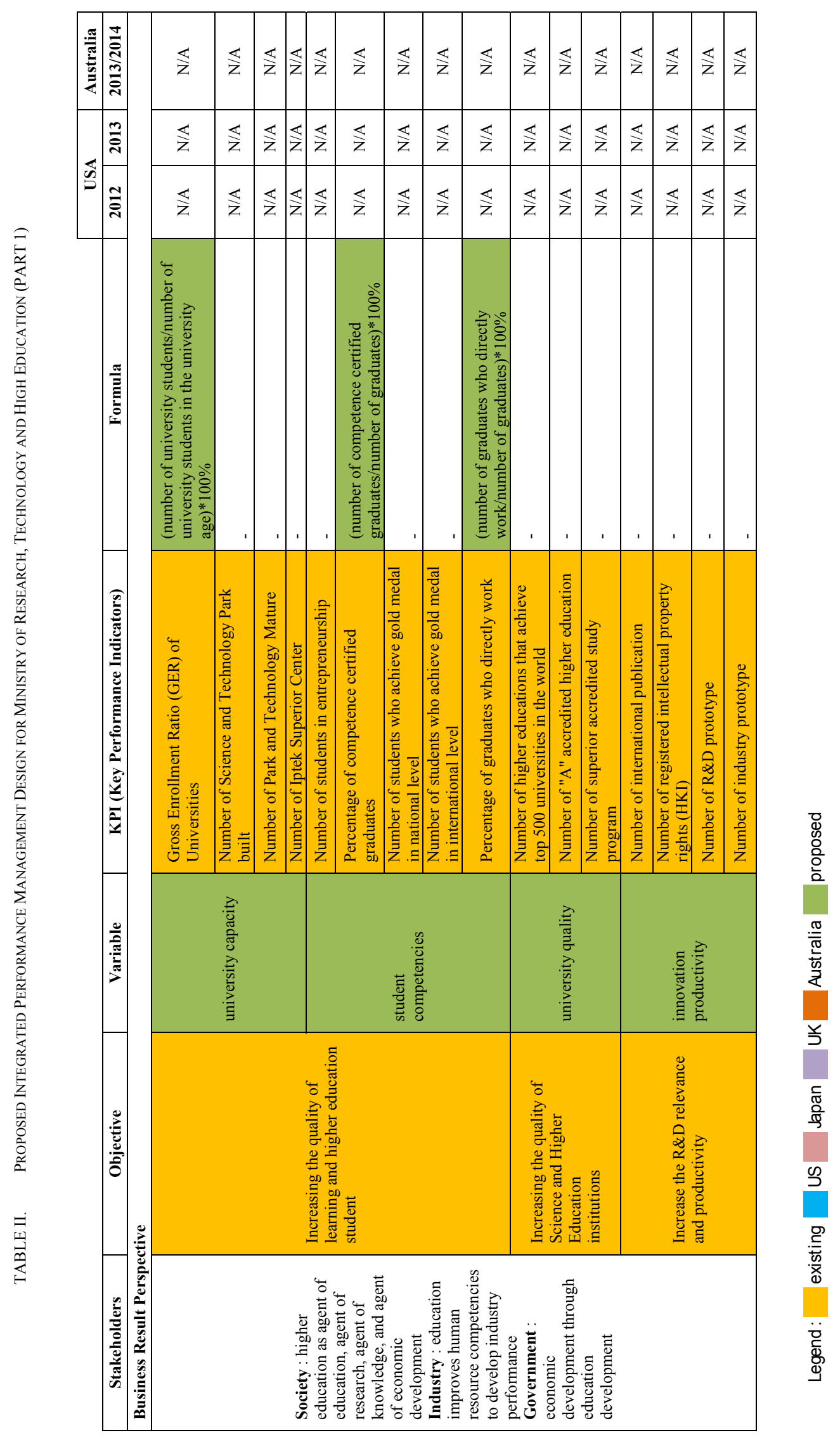




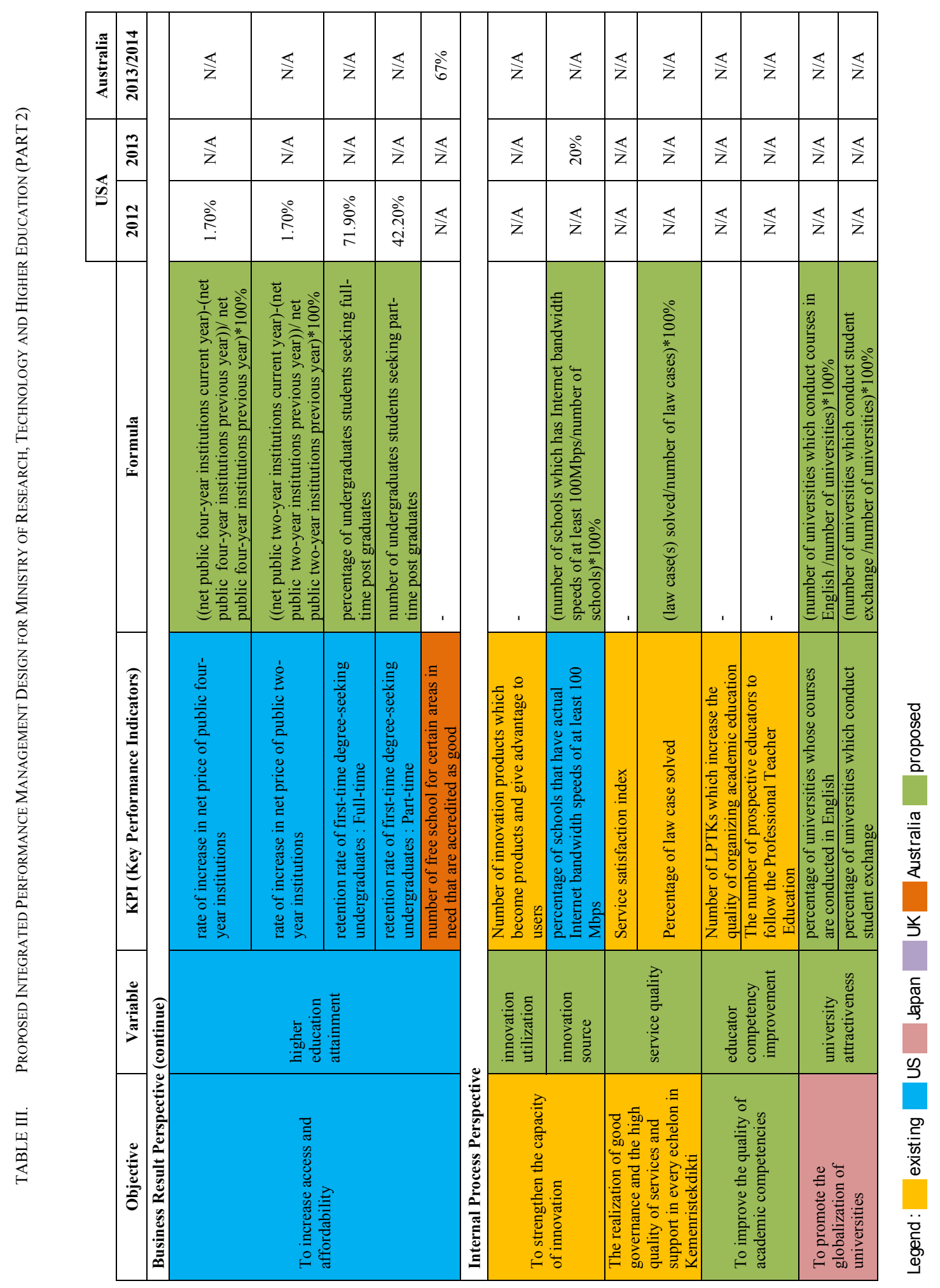




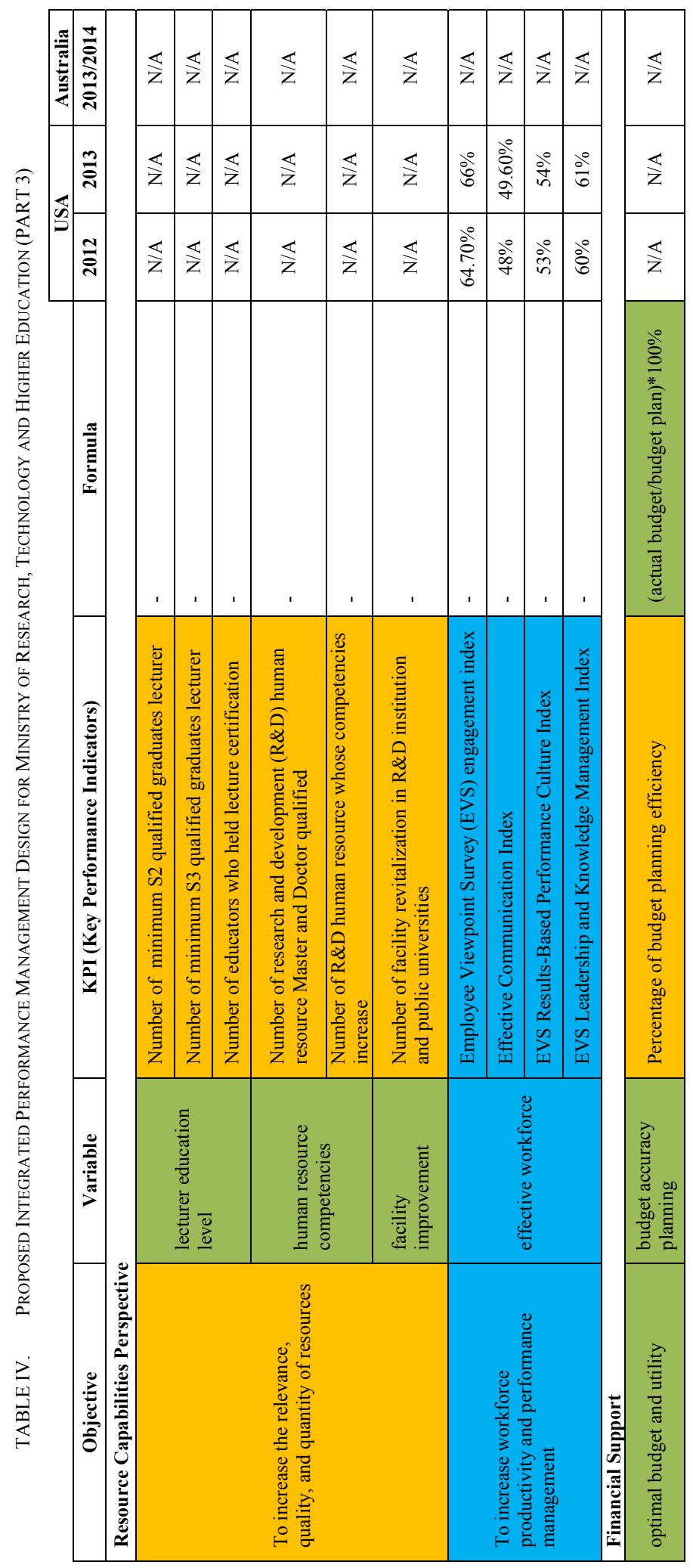


Ministry of Research, Technology and Higher Education is the new ministry formed by Joko Widodo, the elected Indonesia's president in 2014. The existing report and source for this new ministry is the 2015-2019 strategic plan. Therefore, Indonesia's data for 2013 and 2014 is not available.

The adopted KPIs which are taken from USA is included the objective to increase accessibility and affordability (which is related with the objectives of Ministry of Research, Technology and Higher Education) over internet penetration in schools. It is also intended to increase accessibility and affordability of KPI, and workforce over productivity and performance management; which is still lack in the strategic plan of 2015-2019. The adopted KPIs which are taken from Australia are the number of free schools accredited to have good performance. The adopted objective that is proposed is taken from Japan to promote the globalization of universities, to encourage Indonesia's higher education to compete globally.

\section{CONCLUSION AND RECOMMENDATION}

Integrated Performance Management System (IPMS) for Ministry of Research, Technology and Higher Education in Indonesia has been designed in this project. This PMS is expected to be effective to be implemented in Indonesia, because of the simplicity of perspectives and the business result which is not focus only on financial perspective.

The designed IPMS are also taken from some KPIs from developed countries, which enable Indonesia ministries to have suggestion on KPIs and also to encourage ministries to think forward on the medium/long-term objective.

However, this designed IPMS on the ministries should be done on the others ministries in Indonesia in order to achieve more sustainable development. Moreover, the cascading of this designed IPMS is needed, so that the monitoring, evaluation, and follow-up process can be done integrally and systematically. The development of computerization is also required to improve PMS of ministries, so that the resources are not taken for only recording on the performance data, but also to focus on the evaluation and follow-up performance.

\section{Acknowledgment}

Gratefulness to God that this paper can be finished, completed and contributed. Thank you to Professor Wibisono for all the suggestion for this paper completion.

\section{References}

[1] E.G Carayannis, T.D Barth, D.F.J Campbell, "The Quintuple Helix innovation model: global warming as a challenge and driver for innovation", Journal of Innovation and Entrepreneurship, , Vol.1, Issue 2, 2012.

[2] D. Wibisono, "How to Create a World Class Company: Panduan bagi Manajer dan Direktur", PT Gramedia Pustaka Utama, Jakarta,2012, ISBN 978-979-22-9143-8..

[3] F.S Redburn, R.J Shea, and T.e Buss, "Performance Management and Budgeting: How Governments Can Learn From Experience", M.E Sharpe, New York, 2008, ISBN 9780765622334.

[4] J. P Burns and Z. Zhiren, "Performance Management in the Government of the People's Republic of China: Accountability and Control in the
Implementation of Public Policy", OECD Journal on Budgeting, No. 6, Vol. 10, No.2, 2010, pp. 1-28.

[5] Anonymous, "Research and Markets:Latest Theory and Practice of Performance Management System for Nonprofit and Public Sectors", Business Wire, 2008.

[6] T. .L Wheelen and D.J Hunger, "Strategic Management and Business Policy: Toward Global Sustainability",13th edition, New Jersey: Prentice Hall, 2011, ISBN 978-0132153225.

[7] Indonesia's Ministry of Research, Technology and High Education, "2015-2019 Strategic Plan", 2014.

[8] USA's Department of Education, "FY 2014 Annual Performance Report and FY 2016 Annual Performance Plan", 2015.

[9] Australia's Department of Education and Training, " Higher Education Report 2011-2013", 2014. 